\title{
IMPLEMENTASI AKAD WADIAH DALAM PRODUK TABUNGAN DI BANK SYARIAH MANDIRI DAN TINJAUANNYA MENURUT HUKUM EKONOMI SYARIAH
}

\author{
Lulu' Rodiyah \\ Abd Hadi \\ Universitas Muhammadiyah Surabaya \\ Email: lulu.rodiyah.60@gmail.com
}

\begin{abstract}
1 Since Sharia Banking Law issued, Sharia bank is blooming and gaining the trust of people in Indonesia. This is showed by the increase of the number of the established Sharia bank in Indonesia. However, in their practice, these Sharia banks are not in accordance with Islamic law. They plagiarize usury principles from conventional bank and just translate it to Arabic language e.g. Sharia savings and Akad Wadiah.

In principle, the foundation of this product is correct according to Fiqh due to its Wadiah base. However, in their implementation, Sharia bank may applies Wadiah Yad Dhamanah principle; whereas, Akad Wadiah Yad Dhamanah by name can't be found in the classical Fiqh literature, and if this principle is further analyzed, two contradicting Akads which are forcibly combined will be found, i.e. Akad Wadiah and Akad Qard.

This research is field research, where the researcher involved directly in the field or research object i.e. Bank Syariah Mandiri, Lamongan branch. The data is collected by observing and interviewing the management and the employee of Bank Syariah Mandiri, Lamongan branch, thus the collected data is the core of the research object which then analyzed using Qualitative Research method. The result shows that the application of Akad Wadiah in Bank Syariah Mandiri, Lamongan branch is using Wadiah Yad Dhamanah principle, which is not in accordance with the Sharia Economic Law.
\end{abstract}

Keywords: implementation, Wadiah, Sharia Economic Law.

\section{PENDAHULUAN}

Mayoritas penduduk Indonesia adalah beragama Islam, dan dalam Islam semua kegiatan sehara-hari telah di atur dalam Al-qur'an maupun hadits, baik itu dalam beribadah maupun dalam bermuamalah. Dalam bermuamalah, baik dalam berdagang maupun dalam perbankan Islam juga telah mengatur, tidak boleh merugikan pihak lain, harus transparan dan tidak boleh ada unsur riba.

Dalam dunia modern sekarang ini, semua aktivitas manusia baik dalam berbisnis maupun dalam kehidupan seharihari tidak bisa lepas dari berhubungan dengan bank, dan dalam perbankan konvensional tidak bisa lepas dari yang namanya "bunga", dan "bunga bank" identik dengan "riba", sehingga bagi ummat islam ada keraguan jika berhubungan dengan bank, baik dalam berbisnis maupun dalam kehidupan seharihari.

Untuk menjawab keraguan ummat Islam tersebut, kemudian mencullah bankbank dengan menggunakan label islam, selanjutnya keberadaan bank-bank islam tersebut oleh pemerintah diperkuat keberadaannya dengan dikeluarkannya UU no. 21 tahun 2008 tentang Perbankan Syariah.

Dengan diundangkannya UU no. 21 tahun 2008 tentang Perbankan Syariah, perbankan syariah kian marak dan semakin bertambah pula kepercayaan masyarakat Indonesia terhadap keberadaan lembaga keuangan tersebut. Hal ini terlihat dari peningkatan jumlah kuantitas Lembaga Keuangan Syariah yang berdiri dan siap melayani masyarakat Indonesia, namun 
dalam prakteknya bank-bank syariah tersebut nampak dipaksakan, karena masih memplagiasi prinsip riba dari bank konvensional, hanya istilahnya saja yang diubah ke dalam bahasa arab. Ironisnya lagi, di lapangan juga seringkali tidak transparan, misalnya tabungan Wadhia'ah.

Dari permasalahan itulah penulis tergelitik untuk mengupas apa dan bagaimana tabungan wadi'ah menurut Hukum Ekonomi Syariah, dan bagaimana implementasinya dalam dunia perbankan Syariah, khususnya di Bank Syariah Mandiri cabang Lamongan.

\section{Metode Pembahasan \& Landasan Teori.}

\section{A. Metode Pembahasan}

1. Jenis penelitian

Jenis penelitian yang akan digunakan dalam penelitian ini adalah penelitian hukum empiris atau penelitian lapangan. Penelitian hukum empiris yaitu penelitian yang meninjau penerapan hukum di lapangan. Jenis penelitian ini berpangkal dari fakta sosial yang ada di lapangan yang bersinggungan dengan hukum Islam. Penelitian ini merupakan penelitian kualitatif, karena mengandalkan observasi, wawancara, studi dokumentasi dan arsip-arsip yang terkait dengan akad wadiah pada produk tabungan. Oleh karena itu, fokus penelitian ini ditujukan untuk memperoleh kejelasan mengenai pelaksaan akad wadiah pada produk tabungan di Bank Syariah Mandiri cabang Lamongan, serta memperoleh kejelasan mengenai penerapan akad wadiah apakah sudah sesuai dengan Hukum Ekonomi Syariah. Artinya, penelitian ini tidak hanya mengkaji hukum secara teoritis, akan tetapi juga melihat dari sisi praktik dan penerapan hukumnya.

2. Sifat penelitian

Sifat penelitian yang digunakan adalah deskriptif analisis, yaitu menggambarkan hasil penelitian yang berkaitan dengan Aplikasi akad wadiah pada produk tabungan di Bank Syariah Mandiri. Kemudian menganalisis hasil penelitian tersebut berdasarkan kesesuaian dengan teori hukum Ekonomi Syariah.

3. Pendekatan penelitian

Pendekatan penelitian yang akan digunakan oleh peneliti adalah pendekatan penelitian yuridis sosiologis, yaitu sebuah metode penelitian yang digunakan dalam menganalisis data yang diperoleh dari hasil penelitian di lapangan yang kemudian disesuaikan dengan kaidah dan norma hukum Islam yang berkaitan dengan Aplikasi akad wadiah dalam produk tabungan di bank Syariah Mandiri cabang Lamongan menurut hukum Ekonomi Syariah.

4. Sumber data

Sumber data yang akan digunakan dalam penelitian adalah data primer dan sekunder.

Data primer, diperoleh langsung dari sumbernya melalui wawancara, observasi, maupun laporan dalam bentuk dokumen tidak resmi yang kemudian diolah, yaitu data yang didapatkan langsung dari tempat yang menjadi obyek penelitian yaitu pihak-pihak terkait yang ada di Bank Syariah Mandiri cabang Lamongan. Data sekunder, Yaitu sumber lewat dokumen -dokumen resmi, bukubuku, hasil-hasil penelitian dan datadata lain yang berkaitan dengan penerapan akad wadiah dalam produk tabungan di bank Syariah Mandiricabang Lamongan.

5. Metode pengumpulan data

Adapun teknik pengumpulan data adalah :

a. Pengamatan (observasi), Yaitu dengan mengadakan pengamatan ke lokasi, untuk mengetahui Aplikasi akad wadiah dalam 
produk tabungan di bank Syariah Mandiri cabang Lamongan.

b. Wawancara, dengan melakukan tanya jawab secara langsung antara peneliti dengan responden atau narasumber atau informan untuk mendapatkan informasi. untuk mendapatkan data yang dibutuhkan.

Wawancara dilakukan dengan pimpinan cabang bank Syariah Mandiricabang Lamongan, karyawan dan nasabah bank Syariah Mandiri cabang Lamongan.

c. Dokumentasi, yaitu teknik pengumpulan data yang berhubungan dengan obyek penelitian, baik dari buku-buku, koran, majalah dan dokumen lain dalam bentuk tulisan, gambar, atau karya-karya monumental dari seseorang.

6. Metode analisis Data

Setelah data terkumpul semua data yang diinginkan, langkah selanjutnya adalah menganalisis data dan mengambil kesimpulan dari data yang telah terkumpul. Baik data dari hasil wawancara, catatan lapangan dan dokumentasi. dengan menggunakan metode deskriptif dengan pendekatan kualitatif. yaitu peneliti memberikan gambaran secara obyektif terhadap hasil penelitian.

Dalam penelitian ini penulis akan menggambarkan dan menganalisis Aplikasi akad wadiah dalam produk tabungan di bank Syariah Mandiricabang Lamongan menurut hukum Ekonomi Syariah.

\section{B. Landasan Teori.}

1. Pengertian Akad Wadi'ah.

a. Menurut bahasa, Wadi'ah yaitu taraka (meninggalkan), artinya sesuatu yang diletakkan di tempat orang lain oleh untuk djaga. ${ }^{1}$ Secara etimologi Wadi'ah adalah sesuatu yang diletakkan pada yang bukan pemiliknya untuk di pelihara. $^{2}$

b. Menurut istilah,

Para ulama'fikih berdeda-beda dalam mendefinisikan wadiah :

- Mazhab Hanafi mendifinisikan Wadi'ah, adalah mengikut sertakan orang lain dalam memelihara harta, baik dengan ungkapan yang jelas maupun isyarat.

- Mazhab Syafi'i dan maliki, mendifinisikan wadiah adalah mewakilkan orang lain untuk memelihara harta tertentu dengan cara tertentu. ${ }^{3}$ Atau wadiah adalah memberikan kekuasaan orang lain untuk menjaga harta/barangnya secara terang-terangan. Wadi'ah sering disebut sebagai titipan. $^{4}$

- Peraturan Bank Indonesia Nomor $\quad$ 9/19/PBI/2007, Penjelasan Pasal 3 wadi'ah,adalah transaksi penitip dana atau barang dari pemilik kepada penyimpan dana atau barang dengan kewajiban bagi pihak yang menyimpan untuk mengembalikan dana atau barang titipan sewaktu-waktu. ${ }^{5}$

Jadi wadiah adalah merupakan titipan murni yang bersifat tolong menolong antar sesama manusia, ${ }^{6}$

\footnotetext{
1. Rozalinda, Fikih Ekonomi Syariah, (Jakarta,Rajawali Pers, 2017). 159.

2. Wahbah Az-Zuhaili, Fiqih Islam Wa Adillatuhu, (Jakarta Gema Insani, 2011), 556.

3.. $\quad$ Ibid.

4. M. YazidAfandi, Fiqih Mualamalah dan implementasinya dalam lembaga keuangan syariah. (Yogyakarta Logung Pustaka. 2009), 193.

AhmadDahlan, Bank Syariah: Teoritik, Praktik, Kritik, (Yogyakarta: Teras, 2012), 136-137.

6. S.RSjahdeini, Perbankan Islam dan Kedudukannya Dalam Tata Hukun Perbankan Indonesia, (cet. I, Jakarta, Pustaka Utama Grafitti, 1999), 55.
} 
dari satu pihak ke pihak lain, baik individu maupun badan hukum yang harus dijaga dan dikembalikan kapan saja si penitip menghendaki. ${ }^{7}$

2. Dasar Hukum Akad Wadi'ah.

Ulama fikih sependapat bahwa Wadiah adalah salah satu akad dalam rangka tolong menolong antara sesama manusia, hal tersebut didasarkan pada keumuman dalil Alqur'an maupun hadits tentang amanah, yaitu :

a. Al-qur'an :

1) An-Nisa' : 58.

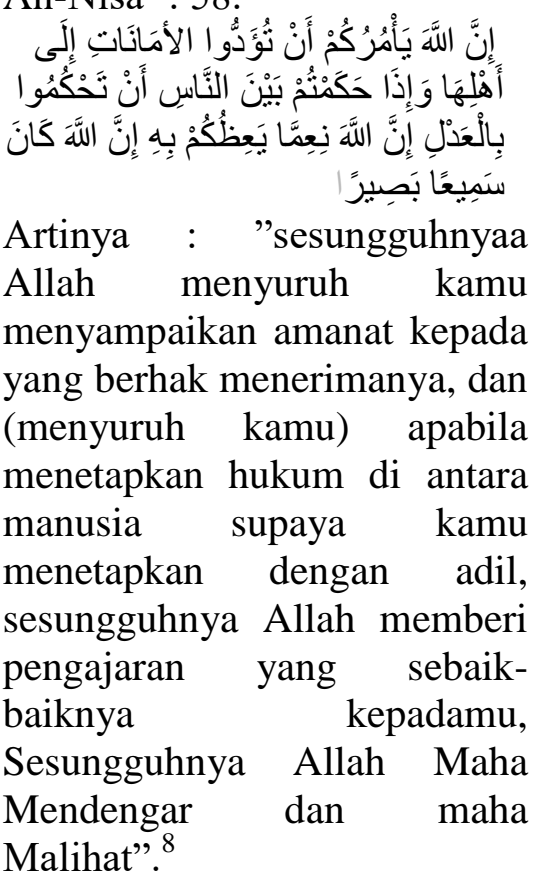

2) Al-Baqoroh : 283.

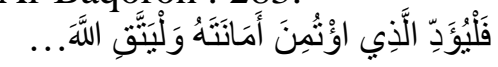

artinya : " Dan hendaklah orang yang diberikan amanatmenyampaikan amanatnya, dan bertakwalah kepada Allah......". 9

b. Hadits :

$$
\begin{aligned}
& \text { اد الأمانة الى من ائتمنك و لا تخن من } \\
& \text { خانك (رواه أبو داود و التز ميذى التي }
\end{aligned}
$$

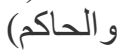

\footnotetext{
7. Muhammad Syafi'iAntonio, Bank Syariah, Suatu Pengenalan Umum.Bank Indonesia dan tazkia Institute.

Al-Quran $2: 282$.
}

Artinya : "Tunaikanlah amanat kepada orang yang memberimu amanat, dan janganlah kamu berkhianat kepa orang yang telah mengkhianatimu" (HR. Abu Daud, Tirmidzi dan Hakim). ${ }^{10}$

3. Jenis-jenis akad wadiah.

Pada dasarnya Wadi'ah titipan yang bersifat amanah, seiring dengan perkembangan dunia usaha, wadi'ah berkembang menjadi 2 jenis, yaitu wadi'ah yad amanah dan wadi'ah yad dhomanah.

a. Wadi'ah yad al-amanah, yaitu titipan murni, orang yang menerima titipan bertanggung jawab barang yang dititipkan kepadanya, orang yang menerima titipan tidak wajib mengganti atau menjamin barang titipan, dan wajib mengembalikan titipan, apabila pemilik barang meminta. Menurut Mazhab Hanafiyah hal tersebut didasarkan pada hadits Rasulullah yang diriwayatkan oleh Daruquthni sebagai berikut:

$$
\text { ولاس على المستعير المستودع غير المغل ضمان ضمان }
$$

"tidak ada kewajiban mengganti barang bagi orang yang menerima titipan yang tidak ada kesia-siaan “ 11

Oleh karena Wadi'ah sifatnya amanah, maka keharusan menjamin ganti rugi atas orang yang diberi amanah, wadi'ah menjadi batal, orang yang mendapat titipan wajib mengembalikan barang titipan kapan pemiliknya meminta. Dan karena akad wadi'ah sifatnya tidak mengikat, masing-masing pihak boleh membatalkan kapanpun mereka

10. Al-Hafidz Ibnu Hajar Al-Asqolani, Bulughul Maram, Jeddah. 182.

11. Rozalinda, Fikih Ekonomi. 162. 
menghendakinya, tanpa perlu adanya ijin pihak lain. ${ }^{12}$

Dari pengertian tersebut dapat disimpulkan bahwa akad wadi'ah yad al- amanah memiliki karakteristik sebagai berikut :

1) Bersifat amanah, Penerima titipan hanya berfungsi sebagai penerimaamanah yang bertugas dan berkewajiban untuk menjaga barang yangdititipkan kepadanya.

2) Harta atau barang yang dititipkan tidak boleh dimanfaatkan atau digunakan oleh penerima titipan.

3) Penerima titipan diperbolehkan untuk meminta biaya kepada yang menitipkan.

4) Penerima titipan tidak berkewajiban mengganti barang yang dititpkan kepadanya apabila barang tersebut rusak atau hilang yang bukan disebabkan karena kelalaiannya.

b. Wadi'ah yad adh-dhamanah, wadi'ah dengan prinsip penggantian, yaitu titipan yang mengandung pengertian bahwa benda yang di titipankan bisa dimanfaatkan oleh penerima titipan. $^{13}$ Keuntungan yang diperoleh dari pemanfaatan barang titipan itu dapat diberikan sebagian kepada pihak pemilik barang/dana dengan syarat tidak diperjanjikan sebelumnya. Namun demikian, penerima titipan harus bertanggung jawab atas barang titipan bila terjadi kerusakan atau kehilangan. ${ }^{14}$

Dari pengertian tersebut diatas, dapat disimpulkan

12. Zuhaili,Fiqih Islam. 561.

13. Rozalinda, Fikih Ekonomi. 166.

${ }^{14}$ H.AJazuli dan Yadi Janwari, Lembaga lembaga Perekonomian umat, sebuah Pengenalan, (PT Raja Grafindo Persada, Jakarta, 2002), 65. bahwa, akad Wadi'ah yad adhdhamanah memiliki karakteristik sebagai berikut :

1) Harta dan barang yang dititipkan boleh dan dapat dimanfaatkan oleh yang menerima titipan.

2) Tidak ada keharusan bagi penerima titipan untuk memberikan hasil pemanfaatan barang titipan kepada pemilik barang. Tapi boleh memberikan bonus.

3) penerima titipan berkewajiban mengganti barang titipan apabiola terjadi kerusakan atau hinag, baik rusaknya tersebut disebabkan karenan kelalaiannya sendiri atau diluar kemampuannya.

Dasar hukum dibolehkannya wadi'ah yad dhamanah dengan memberikan bonus kepada pemilik dana, terdapat pada riwayat Abu daud berikut: "Telah menceritakan kepada kami Al Qa'nabi, dari Malik dari Zaid bin Aslam dari 'Atha' bin Yasar dari Abu Rafi', ia berkata; Rasulullah shallallahu 'alaihi wasallam menghutang seekor unta muda, digunakan untuk berkurban (sedekah). Lalu suatu ketika beliau memerintahkanku agar mengembalikan unta muda tersebut kepada yang punya. Lalu aku katakan; "saya tidak mendapatkan di antara unta tersebut selain unta pilihan yang berumur empat tahun". Kemudian Nabi shallallahu 'alaihi wasallam bersabda: "Berikan kepadanya, sesungguhnya sebaik-baik orang adalah yang terbaik dalam menunaikan hutang."15

Dan juga dalam kasus lain berupa pemanfaatan harta titipan

15. Ibnu Hajar Al-Asqolani, Fathul Baari, penjelasan Kitab : Shahih Al-Bukhari buku 13, Pustaka Azzam, Cet, ketiga, 2010, 375. 
seperti ini pernah dialami oleh Zubair bin 'Awwam. Masyarakat Arab pada saat itu mendatangi Zubair untuk menitipkan harta kekayaannya dengan tujuan melimpahkan penjagaan dan pemeliharaan. Tapi Zubair tidak mau atau tidak rela jika ia tidak diberi hak untuk mentransaksikanya. Dengan catatan Zubair akan menjamin harta tersebut kembali pada pemiliknya. Sehingga dalam penerimaan barang titipan, Zubair tidak mengakui akad wadi'ah, ia mengatakan "tidak, ini adalah pinjaman". ${ }^{16}$

4. Bercampurnya barang titipan dengan barang pribadi.

Seringkali Penerima titipan tidak bisa memisahkan antara barang pribadi dengan barang titipan, terlebih apabila barang titipan itu berupa dana atau uang, hal ini ada beberapa pendapat :

- Menurut Imam Abu Hanifah, hukumnya tidak apa-apa. Apabila tidak mungkin bisa dibedakan (dipisahkan), maka wadi' wajib menanggung ganti-rugi, karena pencampuran harta tersebut merusak barang titipan. Demikiann juga apabila ada penitip, kemudian oleh penerima titipan mencampurkannya, maka penerima titipan wajib menggantinya dengan nilai yang sama. $^{17}$

- Menurut pendapat Syafi'i dan Hanabilah, apabila harta titipan masih bisa dipisahkan dengan harta pribadi (harta sejenis), misalnya dinar dengan dirham, maka tidak ada kewajiban bagi wadi' untuk menanggung ganti rugi. Kecuali terjadi pengurangan nilai dari harta tersebut, ${ }^{18}$

- MenurutImam Malik, apabila barang titipan tersebut tidak memungkinkan untuk dipisahkan, atau jika tujuannya keamanan semata atas harta titipan tersebut,boleh tidak menangung ganti-rugi atas harta yang dicampur, tetapi jika ada tujuan lain dari keamanan, maka wajib menjamin ganti rugi ${ }^{19}$

5. Pemanfaatan Harta Ttitipan.

Barang titipan oleh penerima titipan tidak dibiarkan bergitu saja, tetapi dimanfaatkan dan dikembangkan, terlebih lagi jika barang titipan itu berupa dana. Tentang hukumnya ada beberapa pendapat :

- Menurut Ulama madzhab Maliki, Syafi'i dan Hanbali, Akad wadi'ah bersifat amanah, tidak ada kewajiban atau keharusan mengganti barang titipan, akan tetapi apabila penerima amanah menggunakan/mengambil

manfaat dari barang titipan, maka status wadi'ah yang amanah menjadi batal, sehingga penerima amanah bertanggung jawab mengganti rugi terhadap barang titipan. $^{20}$ walaupun setelah pemakaian terjadi kerusakan atau kehilangan yang disebabkan oleh bencana alam. Karena pemakaian harta titipan berarti telah melanggar amanat, hilang hukum akad titipan. Hukumnya pun dianggap sebagai pelanggaran atas hukum wadi'ah.

- Menurut Imam Hanafi, Apabila harta titipan dimanfaatkan atau dipakai oleh penerima titipan, tidak wajib menggantinya, karena

16. DimyauddinDjuwaini, Pengantar Fiqih Muamalah, (Jogjakarta, Pustakan Pelajar, 2008), 181

17. Zuhaili, Fiqih Islam, 567.

18. Rozalinda,Fikih Ekonomi Syariah.165.

$19^{\circ}$ Zuhaili,Fiqih Islam. 568.

Zuhaili. Fiqih Islam, 565 
dia menjaga benda yang ditipkan kepadanya atas izin pemiliknya.

- Menurut ulama empat madzhab sepakat, jika barang titipan tidak digunakan sama sekali oleh penerima titipan, tidak ada tanggungan ganti rugi. Karena bentuk dan nilai benda masih utuh seperti semula (sewaktu dipegang pemilik). ${ }^{21}$

Bagaimana dengan hukumnya terhadap pemanfaatan keuntungan hasil pengelolaan/pengembangan dari harta titipan, ada beberapa pemdapat :

- Menurut Ulama madzhab

Hanafi, Zufar dan Muhammad

bin Al-Hasan, apabila harta titipan dikelola dan dikembanghkan oleh penitip, maka penerima titipan wajib mengembalikan pokok harta, sedang keuntungannya harus disedekahkan. ${ }^{22}$

- Menurut Imam Malik, Al-Laist dan Abu Yusuf, penerima titipan boleh mengambil keuntungan dari pengelolaan barang titipan tersebut, walaupun ia mengambilnya secara ghosob, ${ }^{23}$

- Menurut sejumlah Ulama' berpendapat, keuntungannya dari harta titipan tersebut menjadi pemilik barang, penerima titipan berhak menerima upah sebatas biaya yang dikenakan untuk menjaga aset yang dititipkan, karena biaya itu merupakan kewajiban pemilik aset. $^{24}$

\section{PEMBAHASAN}

A. Proses pelaksaan akad wadiah di Bank Syariah Mandiri

Produk tabungan BSM adalah salah satu produk yang banyak diminati oleh masyarakat, yaitu jenis tabungan

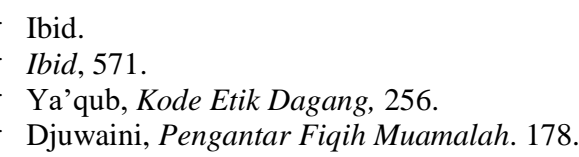

Simpatik (wadiah), Sebagaimana yang telah dijelaskan bahwa Tabungan BSM, berbeda dengan tabungan pada perbankan konvensional, tabungan Simpatik (wadiah) menggunakan akad wadi'ah (penitipan), dengan setoran awal sebesar Rp. 300.000,-, dalam proses pelaksanaannya, nasabah yang hendak menabung, mengemukakan keinginannya, jika nasabah hanya ingin menabung saja, oleh petugas bank disarankan untuk membuka tabungan wadiah, selanjutnya nasabah menyetorkan dananya dengan menggunakan formulir setoran, dan selanjutnya nasabah mendapatkan buku tabungan. Oleh bank, Dana setoran dari nasabah tersebut bercampur dengan dana yang lain, yang selanjutnya oleh bank dikelola untuk dikembangkan.

Nasabah sebagai penitip dana, selain mendapatkan buku tabungan, juga mendapatkan kartu ATM, kartu tersebut dapat digunakan untuk mengambil dananya melalui ATM yang telah tersedia di seluruh Indonesia atau dengan menggunakan buku tabungan, namun dana yang dititipkan tidak bisa diambil seluruhnya sampai nol rupiah, tetapi harus ada saldo minimal sebesar Rp. $\quad 50.000,-$. Nasabah juga mendapatkan fee atau bonus di akhir bulan tanpa diperjanjikan di awal dan tanpa ada prosentase. Penentuan pemberian fee atau bonus tersebut ditentukan atas kebijakan dewan direksi pusat. Nasabah juga bisa transfer ke sesama BSM tanpa biaya.

Adapun kewajiban nasabah, adalah biaya administrasi bulanan, biaya pemeliharaan ATM, dan biaya penutupan rekening sebesar Rp. $20.000,-.^{25}$.

Oleh pihak Bank Syariah Mandiri, dana yang dititipkan oleh nasabah, secara otomatis bercampur dengan dana milik bank atau nasbah yang lain,

\footnotetext{
${ }^{25}$ Hasil wawancara pada tanggal 19 Mei 2019 dengan Alfin (karyawati) pada Bank Syariah Mandiri KC Lamongan
} 
tentunya dana yang ada di bank tidak didiamkan begitu saja oleh bank sebagai pihak penerima titipan, tetapi dikelola dan dikembangkan untuk mendapatkan keuntungan, pihak bank seolah-olah meminta nasabah sebagai penitip untuk memberikan kewenangan kepada pihak bank untuk mengelola titipannya. (karena tidak secara jelas disebutkan dalam akad). Karena bank motifnya adalah ekonomi,pihak bank merasa memiliki hak penuh atas hasil/keuntungan yang diperoleh dari pengelolaan/pemanfaatan barang titipan, dan tidak ada kewajiban untuk membagi hasil/ keuntungan tersebut dengan nasabah sebagai pemilik dana/barang, tetapi atas kebijaksanaan pimpinan pusat, pihak bank dengan suka rela memberikan sebagian keuntungannya kepada nasabah.

\section{B.Analisa}

Dalam masalah ini, ada 2 permasalahan yang penulis analisa, yaitu dari proses pelaksanaan dan administrasinya, serta implementasi akad wadi'ahnya.

1. Proses Pelaksanaan \& Administrasi

Dari proses menabung di Bank Syariah mandiri, apabila dicermati, secara administrasi, baik dalam formulir setoran maupun dalam buku tabungan, tidak ada satupun kalimat yang menjelaskan akad apa yang dipakai dalam tabungan tersebut. danbagaimana hak serta kewajiban, baik bagi nasabah maupun bank sebagai menerima titipan, padahal dalam kegiatan bisnis secara syariah, ada 6 prinsipnya yang harus ditegakkan, diantaranya adalah prinsip Transaksi Keuangan yang Jelas dan tercatat, ${ }^{26}$ artinya setiap transaksi yang terjadi harus dicatat dengan baik, untuk menghindari adanya konflik dan permasalahan dikemudian hari. Hal ini didasarkan pada firman Allah Q.S. Al-Qaqoroh : 282 yang artinya : "Hai orangorang yang beriman, apabila kamu bermu'amalah tidak secara tunai untuk waktu yang ditentukan, hendaklah kamu menuliskannya. Dan hendaklah seorang penulis di antara kamu menuliskannya dengan benar".

Disamping itu, Mengutamakan prinsip Keadilan dan Keseimbangan juga harus diperhatikan, ${ }^{27}$ jangan sampai ketika bertransaksi ada unsur kebohongan, melakukan penipuan, menutupi kekurangan atau kelemahan dari apa yang ditransaksikan. Intinya transaksi harus transparan sehingga tidak ada unsur ghoror didalamnya.

2. Implementasi akad wadiah.

Dari penelitian tersebut, penulis melihat penerapan akad wdi'ah pada tabungan di Bank Syariah Mandiri Cabang Lamongan, ada dua poin terlihat rancu dan tidak sesuai dengan Hukum Islam, yaitu pengelolaan atau pemanfatan dana nasabah sebagai titipan, oleh pihak bank sebagai penerima titipan, dan keuntungan dari pemanfatan dana tersebut merupakan hak penuh bagi bank sebagai penerima titipan, pemilik barang hanya mendapat bonus atas kerelaan bank.

Apabila dilihat dari pelaksaannya, akad wadiah yang diterapkan oleh Bank Syari'ah Mandiri ada beberapa kriteria :

- Dana titipan dikelola oleh bank sebagai penerima titipan,

- Bank sebagai penerima titipan berhak sepenuhnya terhadap keuntungan dari pengelolaan dana titipan.

- pemberian bonus kepada nasabah sebagai penitip mmerupakan

26 Dewi Gemala. Wirdyaningsih, Yeni Salma Barlinti, Hukum Perikatan Islam di Indonesia, Badan Penerbit Fakultas Hukum UI, Jakarta 2005. 37. 
kebijaksaan pimpinan yang tidak diperjanjiakn di awal.

- Bank sebagai penerima titipan, berkewajiban memberikan ganti rugi apabila terdapat kerusakan atau kehilangan atas barang titipan, baik hal tersebut dikarenakan

kesengajaan/kelalaian atau karena bencana alam,

- Nasabah dikenai biaya administrasi.

Apabila dilihat dari kriterian tersebut, akad wadiah yang diterapkan pada Bank Syari'ah Mandiri adalah akad wadhi'ah yad adh-dhamanah, yaitu dengan prinsip penggantian, titipan yang mengandung pengertian bahwa benda yang di titipkan bisa dimanfaatkan oleh penerima titipan. ${ }^{28}$ Keuntungan yang diperoleh dari pemanfaatan barang titipan itu dapat diberikan sebagian kepada pihak yang menitipkan dengan syarat tidak diperjanjikan sebelumnya. Namun demikian, penerima titipan harus bertanggung jawab atas barang titipan bila terjadi kerusakan atau kehilangan. $^{29}$

Dasar hukum dibolehkannya wadi'ah yad dhamanah dengan menyertakan bonus terdapat pada riwayat $\mathrm{Abu}$ daud berikut: "Telah menceritakan kepada kami Al Qa'nabi, dari Malik dari Zaid bin Aslam dari 'Atha' bin Yasar dari Abu Rafi', ia berkata; Rasulullah shallallahu 'alaihi wasallam menghutang seekor unta muda, digunakan untuk berkurban (sedekah). Lalu suatu ketika beliau memerintahkanku agar mengembalikan unta muda tersebut kepada yang punya. Lalu aku katakan ; "saya tidak mendapatkan di antara unta tersebut selain unta pilihan yang berumur empat tahun".

28. Rozalinda, Fikih Ekonomi Syariah, 166.

${ }^{29}$ Jazuli dan Yadi Janwari, Lembaga lembaga, 65.
Kemudian Nabi shallallahu 'alaihi wasallam bersabda: "Berikan kepadanya, sesungguhnya sebaikbaik orang adalah yang terbaik dalam menunaikan hutang". ${ }^{30}$

Dari beberapa pendapat imam madzhab tersebut, dapat disimpulkan bahwa Ulama empat Madzhab sepakat, Akad wadi'ah merupakan suatu akad yang bersifat amanah, tolong menolong antar sesama manusia, ${ }^{31}$ dimana pemilik harta memberikan amanah kepada orang yang dititipi untuk menjaga harta/barangnya. Hal tersebut didasarkan firman Allah dalam surah An-Nisa : 58 :

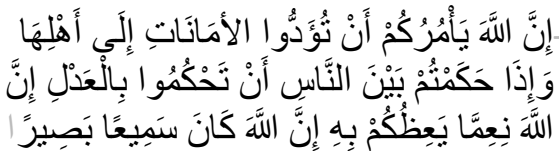

Artinya : "sesungguhnyaa Allah menyuruh kamu menyampaikan amanat kepada yang berhak menerimanya, dan (menyuruh kamu) apabila menetapkan hukum di antara manusia supaya kamu menetapkan dengan adil, sesungguhnya Allah memberi pengajaran yang sebaikbaiknya kepadamu, Sesungguhnya Allah Maha Mendengar dan maha Melihat". 32

Dan juga hadits yang diriwayatkan oleh Abu Daud, Thirmidzi dan Hakim, sebagai berikut :

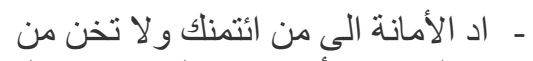$$
\text { خانك (رو اه أبو داود و التر ميذى و الحاكم) }
$$

Artinya : “ Tunaikanlah amanat kepada orang yang memberimu amanat, dan janganlah kamu berkhianat kepa orang yang telah mengkhianatimu" (HR. Abu Daud, Tirmidzi dan Hakim). ${ }^{33}$

Terhadap pengelolaan dana titipan dan mengambil keuntunagn dari barang titipan, oleh pihak bank

\footnotetext{
${ }^{30}$ Al-Asqolani, Fathul Baari, 375.

31. Sjahdeini, Perbankan Islam. 55.

${ }^{32}$ Al-Quran. 4 : 58

33.،Al-Asqolani, Bulughul Maram, 182.
} 
sebagai penerima titipan. Hal itu sudah tidak sesuai dengan hukum Ekonomi Syariah, dimana empat madzhab sepakat bahwa akad wadi'ah adalah amanah, sifatnya murni soaial/ tolong menolong, pemilik harta memberikan amanah kepada bank sebagai pihak yang dititipi untuk menjaga hartanya. Pemanfaatan suatu titipan dalam bentuk apapun hukumnya terlarang, karena apabila telah ada unsur penggunaan/pemanfaatan barang titipan oleh pihak penerima titipan, maka akadnyapun berubah. sedangkan bank Syari'ah motifnya adalah ekonomi,pihak bank merasa memiliki hak penuh atas hasil/ keuntungan yang diperoleh dari pengelolaan/pemanfaatan barang titipan, sehingga sifatnya bukan anamah lagi.

Dari beberapa pendapat ulama', hanya Imam Malik, Al-Laist dan Abu Yusuf, yang membolehkan penerima titipan mengambil keuntungan dari pengelolaan barang titipan tersebut, walaupun dikatakan dengan cara ghosob, yang hal tersebut merupakan perbuatan tercela, karena mengambil keuntungan tanpa ijin dari pihak pemilik barang, tidak ada satupuntand (baik secara explisit maupun implisit) tentang ijinnya bagi penerima titipan untuk mengelola dan mengambil manfaat dari barang titipan.

Sedang dalam berbisnis harus ada saling keterbukaan dan tidak ada unsur yang saling merugikan, walaupun nasabah sebagai pemberi titipan tidak merasa dirugikan, namun apabila dilihat dari nilai ekonomi, tentunya pihak bank sebagai penerima titipan lah yanag sangat diuntungkan, karena dia memperoleh hak penuh terhadap keuntungan dari hasil pengelolaan dana titipan, apalagi masih ada biaya-biaya lain yang dipungut oleh pihak bank sebagai penerima titipan, misalnya biaya administrasi, biaya penutupan buku tabungan, dan salso akhir saat penutupan tabungan.

Bank sebagai penerima titipan hanya berhak menerima upah sebatas biaya yang dikeluarkan untuk menjaga harta. Meminta upah kepada pemilik barang atas jerih payah (menjaga amanat) tidak diperkenankan, karena unsur dasar wadi'ah adalah tolong menolong, bukan mencari sumber kehidupan.

Memberikan kelebihan profit berupa bonus kepada nasabah/pemilik barang, meski tidak ada larangan untuk tidak memberikan bonusnya. Praktik ini tidak dapat dibenarkan karena bertentangan dengan hasil ijtihad para ulama empat madzhab yang diakui dunia. Karena hakikat titipan adalah amanat, bukan pemanfaatan barang titipan yang kemudian dijamin.

Adapun dalil yang dijajdikan dasar hukum Akad wadi'ah yad dhomanah adalah hadis dari Abu Rafi, hadits tersebut, apabila disimak. bukan masalah menitipkan harta, akan tetapi Rasulullah shallallahu 'alaihi wasallam menghutang seekor unta muda untuk berkurban, saat mengembalikan tidak ada unta muda, tetapi ada unta yang berumur empat tahun, jadi ada kelebihan. Hadits ini isinya tentang hutang piutang, demikian juga kasus Zubair bin 'Awwam, dia bukan mengenai menitipkan barang/wadi'ah, tetapi pinjaman (qord). Sehingga kedua hadits tersebut tidak tepat apabila dijadikan dasar hukum akad wadiah, karena kedua hadits diatas akadnya adalah pinjam-meminjam (qord). Bukan titipan.

\section{KESIMPULAN}


Dari pembahasan yang telah penulis paparkan di atas, ada 2 kesimpulan yang dapat diambil :

1. Dalam prosesnya, Akad yang digunakankan dalam produk tabungan di Bank Syari'ah Mandiri nampaknya tidak transparan, karena tidak ada satupun bukti yang menunjukkan tabungan tersebut menggunakan akad wadiah, baik dalam formulir setoran maupun dalam dalam buku tabungan itu sendiri, padahal kegiatan dalam Ekonomi Islam, harus memperhatikan prinsip-prinsip yang ada dalam Ekonomi Islam, diantaranya prinsip Transaksi Keuangan yang Jelas dan tercatat, serta prinsip Mengutamakan Keadilan dan Keseimbangan.

2. Wadiah adalah akad titipan. dalam prakteknya di bank syariah khususnya Bank Syariah Mandiri, akad wadiah diterapkan dalam produk tabungan dan giro yang bernama Tabungan Simpatik dan BSM Giro. Akad wadiah yang dipergunakan dalam kedua produk tersebut adalah akadwadiah yad dhamanah. dimana pihak bank sebagai penerima titipan, mempunyai hak penuh untuk mengelola dan memanfaatkan dana titipan dari nasabahnya dan berhak penuh atas hasil/keuntungan dari pengelolaan dana tersebut, sedang pemberian bonus kepada pemilik dana merupakan kebijakana pimpinan pusat dari bank itu sendiri,dan bank sebagai penerima titipan berkewajiban memberikan ganti rugi apabila terdapat kerusakan atau kehilangan atas barang titipan, baik hal tersebut dikarenakan kesengajaan/kelalaian atau karena bencana alam.

Sedangkan menurut hukum ekonomi syariah, ulama sepakad akad wadiah adalah amanah, murni tolong menolong, dengan tujuan ibadah, sedangkan bank tujuannya adalah ekonomi,sehingga akad wadhiah yang dipraktekkan di Bank Syariah Mandiri tidak sesuai dengan hukum ekonomi syariah.

Penerapan akad wadhiah dengan menggunakan wadhiah yad dhomanah dalam perbakan syariah, nampaknya dipaksakan demi untuk menjaring nasabah sebanyak-banyaknya, dimana mayoritas penduduk Indonesia adalah beragama Islam, juga demi mencari kepercayaan dari nasabahnya.

\section{DAFTAR PUSTAKA}

Al-Quran dan Terjemahannya, Yayasan Penyelenggara Penerjemahpenafsir Al-quran,Jakarta, 1993.

Al-Asqolani,Al-Hafidz Ibnu Hajar, Bulughul Maram, Jeddah.,Fathul Baari, penjelasan Kitab : Shahih Al-Bukhari buku 13, Pustaka Azzam, Cet, ketiga, 2010.

Afandi,M. Yazid, Fiqih Mualamalah dan implementasinya dalam lembaga keuangan syariah . Yogyakarta Logung Pustaka. 2009.

Antonio,Muhammad Syafi'i, Bank Syariah :Dari Teori ke Praktek. Jakarta GIP. 2001.

Arikunto,Suharsimi, Prosedur Penelitian Suatu Pendekatan Praktek, Jakarta: PT. Rineka Cipta Persada, 2003.

Az-Zuhaili,Wahbah, Fiqih Islam Wa Adillatuhu, Jakarta Gema Insani, 2011.

Dahlan,Ahmad, Bank Syariah: Teoritik, Praktik, Kritik, Yogyakarta: Teras, 2012.

Djuwaini, Dimyauddin, Pengantar Fiqih Muamalah,Jogjakarta, Pustakan Pelajar, 2008.

Fajar,Mukti, Dualisme penelitian Hukum Normatif dan Empiris, Yogyakarta: Pustaka pelajar, 2015.

Gemala Dewi. Wirdyaningsih, Yeni Salma Barlinti, Hukum Perikatan Islam di Indonesia, Badan Penerbit Fakultas Hukum UI, Jakarta 2005.

Hassan,M. Ali, Berbagai Macam Transaksi dalam Islam, Fiqih Muamalah, Jakarta : PT Raja Grafindo persada, 2004. 
Jazuli, H.A. Jazuli dan Yadi Janwari, Lembaga lembaga Perekonomian umat, sebuah Pengenalan, PT Raja Grafindo Persada, Jakarta, 2002.

Karim,Adiwarman A., Bank Islam Analisa fiqih dan Keuangan, edisi ketiga, Jakarta, PT. Raja Grafindo Persada.

Muhammad, Manajemen Pembiayaan Mudharabah di Bank Syariah, Jakarta: PT Raja Grafindo Persada, 2008.

Nasution,Bahder Johan, Metode Penelitian Ilmu Hukum, Bandung: CV. Mandar Maju, 2008.

Nurul Ichsan,Hasan, Perbankan Syariah: Sebuah Pengantar, Ciputat: Referensi GP Press Group, 2014.

Nawawi,Hadari, Metode Penelitian Bidang Sosial, Yogyakarta: Gadjah Mada University Press, 1998.

Nazir,Muhammad, Metode Penelitian, Jakarta: Ghalia Indonesia, 1998.

Rozalinda, Fikih Ekonomi Syariah, Jakarta,Rajawali Pers, 2017.

Soerjono,Soekanto, Pengantar penelitian Hukum, Jakarta: Ui Press, 2006.

Sugiyono, Metode Penelitian Kuantitatif Kualitatif Dan R \& D, Bandung: Alfabeta, 200).

Sjahdeini,S.R, Perbankan Islam dan Kedudukannya Dalam Tata Hukun Perbankan Indonesia, cet. I, Jakarta, Pustaka Utama Grafitti, 1999.

Sumarsono,Sonny, Metode Riset Sumber Daya Manusia, Yogyakarta: Graha Ilmu, 2004.

Undang-Undang No. 21 Tahun 2008tentang Perbankan Syariah.

Wiroso, Penghimpunana Dana dan Hasil Usaha Bank Syariah, Jakarta: PT Grasindo, 200).

Ya’qub,Hamzah, Kode Etik Dagang menurut Islam, Bandung, Diponegoro, 1984.

Pedoman Penulisan Tesis \& Artikel Ilmiyah, Program Pascasarjana Universitas Muhammadiyah Surabaya, 2018.

Peraturan Bank Indonesia Tahun 1999 Tentang Petunjuk Pelaksanaan Pembukaan Kantor Bank Syariah.

Hasil wawancara pada tanggal 19 April 2019 dengan Rizal Fananie, Branch Manager pada Bank Syariah Mandiri KC Lamongan.

Hasil wawancara pada tanggal 19 Mei 2019 dengan Alfin (karyawati) pada Bank Syariah Mandiri KC Lamongan. 